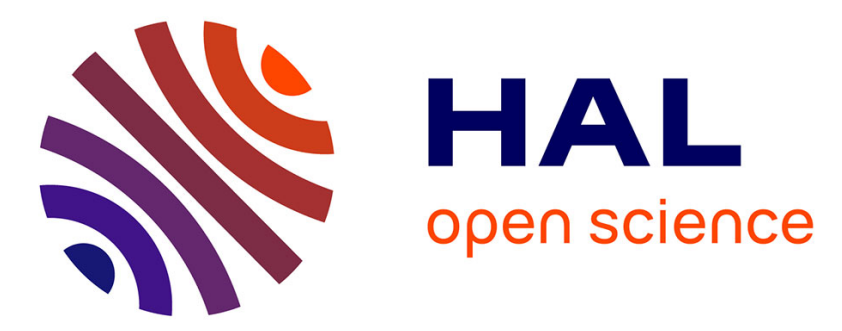

\title{
What expert patients report that they do in the French health care system, and the competencies and personality traits required
}

\author{
Olivia Gross, Rémi Gagnayre
}

\section{- To cite this version:}

Olivia Gross, Rémi Gagnayre. What expert patients report that they do in the French health care system, and the competencies and personality traits required. Éducation thérapeutique du patient / Therapeutic patient education , 2014, 6 (2), pp.20104 - 20104. 10.1051/tpe/2014014 . hal-01557358

\section{HAL Id: hal-01557358 https://sorbonne-paris-nord.hal.science/hal-01557358}

Submitted on 6 Jul 2017

HAL is a multi-disciplinary open access archive for the deposit and dissemination of scientific research documents, whether they are published or not. The documents may come from teaching and research institutions in France or abroad, or from public or private research centers.
L'archive ouverte pluridisciplinaire HAL, est destinée au dépôt et à la diffusion de documents scientifiques de niveau recherche, publiés ou non, émanant des établissements d'enseignement et de recherche français ou étrangers, des laboratoires publics ou privés. 


\title{
What expert patients report that they do in the French health care system, and the competencies and personality traits required
}

\author{
Olivia Gross, Rémi Gagnayre \\ Laboratoire Éducations et Pratiques de Santé (Pédagogie de la Santé) - EA3412, UFR Santé-Médecine et Biologie Humaine - Université \\ Paris 13, 74, rue Marcel Cachin, 93017 Bobigny, France
}

(Received 1st August 2014, accepted 6th October 2014)

\begin{abstract}
Context: Some patients, known as expert patients, strive to improve the performance of the health care system. The precise nature of their activities, skills and personality traits are unclear however, which could compromise their recognition. Methods: This study was conducted based on the assumptions of methodological individualism and social constructivism. We identified twelve expert patients using a judgment sampling technique and asked them to give accounts of their practices. We then performed thematic and categorical data analysis. Results: We identified the activities that these patients engage in when they are acting as expert-patients. From that characterisation we determined that their core competency was "to improve the management and/or prevention of the illness." In practicing that core competency they make use of thirteen competencies in the realms of self-reliance and intercultural and emotional competence. Their personality traits are on the order of emotional intelligence. Discussion: These results help us better understand the nature of expert patients' actions and their contribution to the health care system. These should make it easier for traditional actors to identify and recruit them, as recommended by the World Health Organisation. They could also be used as pedagogical benchmarks in a potential (self-) training process.
\end{abstract}

Key words: expert patients / self-reliance skills / intercultural skills / emotional skills / emotional intelligence

\begin{abstract}
Résumé - Ce que les patients-experts rapportent de leurs activités dans le système de santé français et les compétences et traits de personnalité nécessaires pour les réaliser. Contexte : Certains patients, dits des patientsexperts, cherchent à rendre le système de santé plus performant. Toutefois, la nature exacte de leurs activités, de leurs compétences, et celle de leurs traits de personnalité restent flous ce qui nuit à leur reconnaissance. Méthode : La recherche a été réalisée à partir des présupposés de l'individualisme méthodologique et du socioconstructivisme. Nous avons identifié 12 patients-experts selon une technique d'échantillonnage par choix raisonné et avons recueilli leurs récits de pratique. Il a été procédé à une analyse thématique et catégorielle. Résultats : Nous avons repéré les activités qui servent l'engagement de ces patients en tant que patients-experts. Cette caractérisation a permis de déterminer deux types distincts de patients-experts portés pour l'un sur les problématiques biomédicales de la maladie et pour l'autre sur ses problématiques psychosociales. Tous deux cherchent à « Améliorer la prise en charge et/ou la prévention de la maladie ». A cet effet, ils sollicitent 13 compétences qui sont du registre des compétences de l'autonomie, interculturelles et émotionnelles. Quant à leurs traits de personnalité, ils renvoient aux caractéristiques de l'intelligence émotionnelle. Discussion : Ces résultats donnent un cadre permettant de mieux comprendre la nature des actions des patients-experts et celle de leur contribution au système de santé. Ils devraient faciliter leur identification et donc, comme promu par l'Organisation Mondiale de la Santé, leur recrutement auprès des acteurs traditionnels. Ils pourraient également servir d'outils pédagogiques puisqu'ils permettent d'envisager des dispositifs d'auto formations et de formation.
\end{abstract}

Mots clés : patients-experts / compétences de l'autonomie / compétences interculturelles / compétences émotionnelles / intelligence émotionnelle

\section{Introduction}

Despite Ottawa Charter for Health Promotion (WHO, 1986) directives, health interventions still alternate between

\footnotetext{
^ Correspondence: remi.gagnayre@ univ-paris13.fr
}

"top down" models that protect traditional experts' monopoly over health expertise and "bottom up" models that support a more deliberative view of the decision-making process. These conflicting models are a source of tension, particularly among health promotion specialists [1]. These same controversies 
exist with respect to public health expertise. Indeed, some suggest that to improve how it is received, the selection of expertise should be more restrictive [2], while others [3] recommend expanding participation in the expertise process to include the people concerned. Opposition to the latter proposal is very likely due to the fact that no one really knows what patients can offer the health care system, although practices developed by some patients indicate that such patients have become experts in their disease and/or the health care system. While the expertise of patient organisations has been analysed and recognised $[4,5]$, the same is generally not true for the patients who make up their membership.

Moreover, there is no definitively established name for such patients, though they are usually called expert patients [6], especially in the field of therapeutic patient education. Since patient activity in the French health care system extends beyond therapeutic education, there is no reason why that term should be reserved for just one area of intervention. While a few studies have described activities expert patients are involved in, such as medical training [7] or therapeutic education [8] few have tied these activities to specific competencies, apart perhaps from the medical training latter study.

The aim of this study is to define the activities and associated competencies of a group of twelve expert patients and to identify their specific personality traits.

This characterisation should facilitate the recognition of expert patients and hence their participation in the French health care system where their numbers are still limited and where as evidenced by Grimaldi's perplexity [9], the exact nature of their contribution is not yet fully understood.

\section{Methods}

\subsection{Theoretical framework}

To conduct this study, we developed a conceptual framework with three main components:

- a paradigmatic component that borrows from social constructivism, which posits that the construction of expert patient knowledge is a cultural, collaborative act;

- a conceptual component that refers to the concepts of expert, expertise and competencies;

- a theoretical component based on methodological individualism, which has led us to conduct an inductive, qualitative study, to make use of the actors words, and to understand the (health care) system based on their adaptation strategies.

\subsection{Study population}

A "patient" is considered anyone involved as a consumer in a health care relationship who has consented to care, whether sick or related to someone who is sick.
Expert patients were identified for participation in the study by judgment sampling and by network. An initial sample was assembled by soliciting expert patients within institutional committees. However, to avoid basing the selection on this one criterion and to avoid any bias we also recruited patients who had participated as experts in conferences alongside traditional experts. Lastly, we asked these two groups to recruit patients that they would qualify as expert patients. In the end, all of the expert patients in the study reported multiple activities but for the most part they were lobbyists, dedicated to improving the well-being of their peers, patient trainers, involved in a way or another in medical research, or user representatives on various committees.

\subsection{Data collection and analysis method}

The study data were obtained using semi-directive interviews encouraging expert patients to give accounts of their practices. The interviews were recorded and transcribed. According to the recommendations [10], twelve expert patients were sufficient for data saturation in the areas concerned by the analysis.

First, we used a thematic and categorical analysis of the expert patients' accounts to identify expert-patient activities. Then, to come up with a list of potential expert-patient competences, we looked for the procedural knowledge necessary to the successful conduct of their activities.

The units of meaning were ordered according to skills relating to communication (show-how), analysis (know-why), know-how, and from this so-called "contributory" objectives emerged. The latter were then grouped according to their logical relationships to a specific action and assigned to competency.

To identify their personality traits, we asked the expert patients to state which traits were useful to their expert-patient activities. We did not give them a strict definition of "traits" in order not to influence their answers, nor did we add our own interpretation - we stuck strictly to what they told us.

We ordered those traits according to whether they involved access to the cognitive, to the self, or to others, and then attempted to link our results to existing models.

The same content analysis was conducted by an outside researcher to satisfy the credibility criterion. Comparisons were made at each phase of the analysis to give a ruling on the units of meaning and the categorisations.

Each phase of the study involved ethical considerations. The protocol was shared with the participants prior to the first meeting and all gave their written consent to participate in the study. They were later asked to comment on, criticise and deepen the analysis that had been done. This ethical commitment reinforced the validity of the results and the originality of the study, since the results presented garnered support from the people concerned, who - consistent with our theoretical choices - were treated as credible, competent actors at every level. 
Table I. Typology of actions carried out by expert patients that help improve the care system and/or prevention of illness(es). - Cadre des activités menées par les patients-experts afin d'améliorer la prise en charge et/ou la prévention de la maladie.

\begin{tabular}{|l|l|l|l|l|l|}
\hline $\begin{array}{l}\text { Type of } \\
\text { the action }\end{array}$ & Innovation & Support & Training & $\begin{array}{l}\text { Information/ } \\
\text { lobbying }\end{array}$ & $\begin{array}{l}\text { Participation } \\
\text { in health } \\
\text { democracy }\end{array}$ \\
\hline $\begin{array}{l}\text { What or } \\
\text { who is } \\
\text { concerned } \\
\text { by the action }\end{array}$ & $\begin{array}{l}\text { The therapeutics } \\
\text { The access to care } \\
\text { The medical }\end{array}$ & $\begin{array}{l}\text { To patients } \\
\text { To care givers }\end{array}$ & $\begin{array}{l}\text { To patients } \\
\text { To health } \\
\text { professionals }\end{array}$ & $\begin{array}{l}\text { To patients, } \\
\text { To care givers } \\
\text { To professionals } \\
\text { (including politics) } \\
\text { To at-risk populations } \\
\text { To general public }\end{array}$ & $\begin{array}{l}\text { The exercice of rights } \\
\text { pubtions aimed at } \\
\text { advancing patients } \\
\text { rights }\end{array}$ \\
\hline
\end{tabular}

\section{Results and discussion}

\subsection{Expert-patient activities}

\subsubsection{Two types of expert patients}

The study patients, called expert patients, try to help improve the health care system. To that end they explore all areas of disease management; they regard nothing as off-limits to them, even areas known to be reserved for professionals (see Tab. I). However, they rarely engage in all types of action at once, tending to devote themselves to one particular health-related area. More precisely, two types of expert patients emerged: the first type gets involved with the treatment and pathophysiology of the disease that concerns them, and the second type with health care system-related and social issues and daily life with the disease.

\subsubsection{Expert patients' relationship to their own care}

While both of these expert patient types behave like informed consumers when choosing their doctor(s), they have a different relationship to their care and care providers. Biomedical type expert patients feel free to suggest treatment options, or even try to force them on their doctor, and they coordinate their own care. They engage in treatment activism, like that described in AIDS [11], and are able to initiate and manage largescale projects; some of the expert patients in our study conduct community research projects, and one expert patient launched and coordinates translational research on an extremely innovative gene therapy project. In so doing, these expert patients are attempting to decompartmentalise the medical and scientific disciplines.

Expert patients whose core expertise is not in the realm of science, on the other hand, tend to comply more readily with their doctors' decisions - provided, however, that they experience their relationship with the doctor as a true partnership.

\subsubsection{Deontology and self-positioning}

Some of these latter expert patients are constantly engaged in support or medical/social education activities on behalf of their fellow patients; they do this via organisations, websites or specially designated spaces within hospitals. The medical information they make available to their peers via websites or magazines is generally checked by health professionals, though often written by the expert patients themselves to speed up the process. These expert patients have their own set of rules, similar to medical ethics. They are careful not to confuse their personal history with those of the people they support, or to interfere in purely medical problems; should the latter occur, they direct people to the appropriate physician. They do not, however, respect the same boundaries when it comes to psychosocial issues, and provide patient support without realizing that they may in fact be encroaching upon the territory of professionals in these sectors.

The current growth of therapeutic education is driving the same type of expert patient into that field. They are often involved as peer educators in therapeutic education programs at the hospital or organisational level, after taking the same type of training course as health professionals.

\subsubsection{Lobbying and participation in health democracy}

Once they have identified necessary medical and social improvements, some expert patients fight for health care device reimbursement to expand the use of medical techniques, and for rights - disability rights, in particular. The expert patients who participate in these types of actions do so with mandates from their patient organization, though not necessarily as part of a health democracy mission, in the sense of France's March 2002 patients' rights law. The credo of those who do fit the latter category is "participate, act, and influence". When their contribution is to sit on committees that deal with more than just their own illness, they demonstrate a strong degree of abstraction from their personal history, and it is doubtless in that activity that they most embody the role of spokesperson.

\subsubsection{Improving the patient-doctor relationship}

Some expert patients also try to improve the doctor-patient relationship. Such expert patients have three options open to them: to become a health care mediator; to use their ingenuity to convey messages through chance informal encounters, 
being tactful and strategic to avoid hurting the caregiver's feelings; or to get involved in the initial training of health professionals as a patient-trainer. Note that the patient-trainers in our study do not just pursue that one objective, but try to convey medical and social messages as well.

\subsubsection{Prevention}

Lastly, some expert patients engage in prevention-related activities. Such expert patients show a sense of membership beyond the community, since they want to act on behalf of people who are different from them, who are not yet sick; they want to prevent them from becoming sick at any price, to prevent them from having to go through what they themselves have suffered. This requires that they be capable of designing education campaigns aimed at an audience that is nothing at all like who they are now, or even with who they were before, since they themselves were sick, and the context has changed over time. Their legitimacy in carrying out such prevention activities is thus based on their motivation and their experience of that practice, and not at all on their life experience. So in that situation they are very like traditional experts, and the justification for their involvement is not solely their experiential knowledge.

\subsection{Expert patient competencies}

By competencie we are referring to the definition by Leclercq [12] based on that of Beckers et al.: "the ability to act effectively in families of complex situations by mobilising internal and external resources with a reflexive attitude and a concern for continuous development".

Thirteen competencies were identified based on the study of expert patients' activities. Each of them, to be fully achieved, need from two to six contributory objectives. We found a total of 50 contributory objectives that precisely reflect expert patients' ways of doing their activities.

They contribute to the following key competency: "To help improve the care system and prevention of the illness" (Tab. II).

Another thematic analysis was done in order to better capture the thirteen competencies and their contributive objectives. Three types of competencies emerged that borrow from self-reliance as characterized by Perrenoud [13], intercultural and emotional competencies.

Self-reliance competencies are essential to expert patients because, aside from the specific case of health democracy, which has assigned patient's precise missions, there are no dedicated structures for them; they have to think up, initiate, and in most cases carry out the projects that help fill the needs they have identified.

Their interactions with both peers and professionals also require intercultural competencies, which are " a set of cognitive, affective, and behavioral skills and characteristics that support effective and appropriate interaction in a variety of cultural contexts" [14]. Indeed, their expertise seems to derive especially from their ability to participate in medical, social and political bodies. They have a talent for establishing interdisciplinary relationships; they grasp the elements of language, the codes and the values of disciplines and circles not their own, demonstrate empathy with some and professionalism with others. But while they are able to make enriching forays into cultures very different from their own, they do so without giving up their layman's view, as a person concerned; they do not assimilate. Reference to interculturality thus allows us to clarify the nature of the skill for adapting to the medi$\mathrm{cal} /$ scientific setting; it involves becoming a participant [15].

Finally, expert patients demonstrate emotional competencies, thanks to which they manage to get something back (emotionally), in the sense that they lose the sense of powerlessness that all illness causes and gain a sense of personal efficacy. They adapt perfectly to different situations, even confrontational or difficult ones, because they derive an additional source of motivation. Emotional skills thus help them stay motivated over the long-term (which is necessary so that all the other skills can develop), enabling them to have an accurate idea of their expectations and of their personal and systemic situation.

Most of the contributory objectives are either communication skills (show-how), analytical skills (know-why), knowhow and well-being as shown in Figure 1. The analytical skills (know-why) reflect the expert patients' ability to assess their needs and assets, interpret the systemic issues and take stock of the current situation and knowledge. The know-how reflects their ability to access knowledge, implement the actions they devise and interact socially in a variety of settings. Lastly, their communication skills (show-how) lead them to cultivate signs of expertise, to be objective about their own history so that they can act as spokespeople for their fellow patients, and to spread their knowledge - including academic knowledge - in some cases from one specialist to another, thus confirming their role as "decompartmentalisers".

\subsection{Personality traits of expert patients}

Acting as expert patients enabled patients to get past their initial vulnerability, or restrict their episodes of vulnerability to certain times and places. They were thus able to overcome the devastating emotion of the disease and channel it. That accomplishment can be understood in terms of emotional intelligence "emotional intelligence is observed when a person demonstrates the competencies that constitute self-awareness, self-management, social awareness, and social skills at appropriate times and ways in sufficient frequency to be effective in the situation" [16].

Indeed, it is easy to imagine the emotional damage caused by illness and, symmetrically, the emotional strength needed not just to overcome, but to become an actor and expert in that illness. While illness is usually described as leading to low self-esteem, expert patients' accomplishments enhanced their self-esteem and feeling of self-efficacy [17]. 
Table II. Expert patients competencies fitting the following key competency "Improving the care system and/or the prevention of the illness". - Les compétences des patients-experts permettant d'améliorer la prise en charge et/ou la prévention de la maladie.

\begin{tabular}{|c|c|}
\hline Competencies & Contributory objectives \\
\hline 1) Access to knowledge, share it & $\begin{array}{l}\text { To access academic knowledge } \\
\text { To know the current state of research and treatment } \\
\text { To update own knowledge regularly } \\
\text { To navigate among different groups } \\
\text { To know which information to circulate, and to whom }\end{array}$ \\
\hline $\begin{array}{l}\text { 2) Produce knowledge and } \\
\text { innovation, share it }\end{array}$ & $\begin{array}{l}\text { To identify the limits of knowledge } \\
\text { To stimulate research } \\
\text { To identify medical innovations } \\
\text { To share innovations with fellow patients } \\
\text { To share innovations with professionals }\end{array}$ \\
\hline $\begin{array}{l}\text { 3) Diagnose the situation and } \\
\text { envision possible solutions }\end{array}$ & $\begin{array}{l}\text { To assess situations } \\
\text { To identify areas for improvement }\end{array}$ \\
\hline $\begin{array}{l}\text { 4) Access the loci of decision-making } \\
\text { and propose potential solutions with } \\
\text { conviction and supporting arguments }\end{array}$ & $\begin{array}{l}\text { To access the loci of decision-making } \\
\text { To communicate own ideas }\end{array}$ \\
\hline 5) Envision and implement projects & $\begin{array}{l}\text { To design, create and steer projects } \\
\text { To lead collaborative efforts, including transdisciplinary ones } \\
\text { To find project funding } \\
\text { To anticipate the consequences of actions }\end{array}$ \\
\hline $\begin{array}{l}\text { 6) Play with the rules, use them } \\
\text { and change them }\end{array}$ & $\begin{array}{l}\text { To master the standards and values of the setting } \\
\text { To submit to disciplinary requirements } \\
\text { To interact with institutions to change the rules }\end{array}$ \\
\hline 7) Train, educate and support & $\begin{array}{l}\text { To train fellow patients } \\
\text { To train professionals } \\
\text { To set up support systems } \\
\text { To direct people, when necessary, to the appropriate professional } \\
\text { To educate the target audience } \\
\text { To share own practices }\end{array}$ \\
\hline $\begin{array}{l}\text { 8) Build a resource network } \\
\text { in different settings and fields }\end{array}$ & $\begin{array}{l}\text { To enlist others } \\
\text { To build networks among patients, fellow experts } \\
\text { To build networks among professionals }\end{array}$ \\
\hline $\begin{array}{l}\text { 9) Construct negotiated orders } \\
\text { across cultural differences }\end{array}$ & $\begin{array}{l}\text { To understand and respect others' standards and discourse } \\
\text { To penetrate decision-making bodies and become part of them } \\
\text { To master scientific language }\end{array}$ \\
\hline $\begin{array}{l}\text { 10) Analyse relationships and } \\
\text { identify the systemic issues }\end{array}$ & $\begin{array}{l}\text { To be able to identify and understand what is obstructing systemic forces } \\
\text { To identify the interests and motivations of interested parties }\end{array}$ \\
\hline 11) Stay motivated over the long term & $\begin{array}{l}\text { To tolerate stress and conflict } \\
\text { To develop signs of expertise } \\
\text { To feel legitimate } \\
\text { To appear legitimate }\end{array}$ \\
\hline 12) Self-analysis competencies & $\begin{array}{l}\text { To be aware of own health status } \\
\text { To identify own resources } \\
\text { To identify own motivations } \\
\text { To identify own limits and strengths } \\
\text { To know own expectations in terms of health care } \\
\text { To represent others }\end{array}$ \\
\hline 13) Contribute to own care & $\begin{array}{l}\text { To create a balanced care partnership } \\
\text { To anticipate complication episodes } \\
\text { To be proactive in making suggestions } \\
\text { To coordinate own care } \\
\text { To choose own doctor }\end{array}$ \\
\hline
\end{tabular}




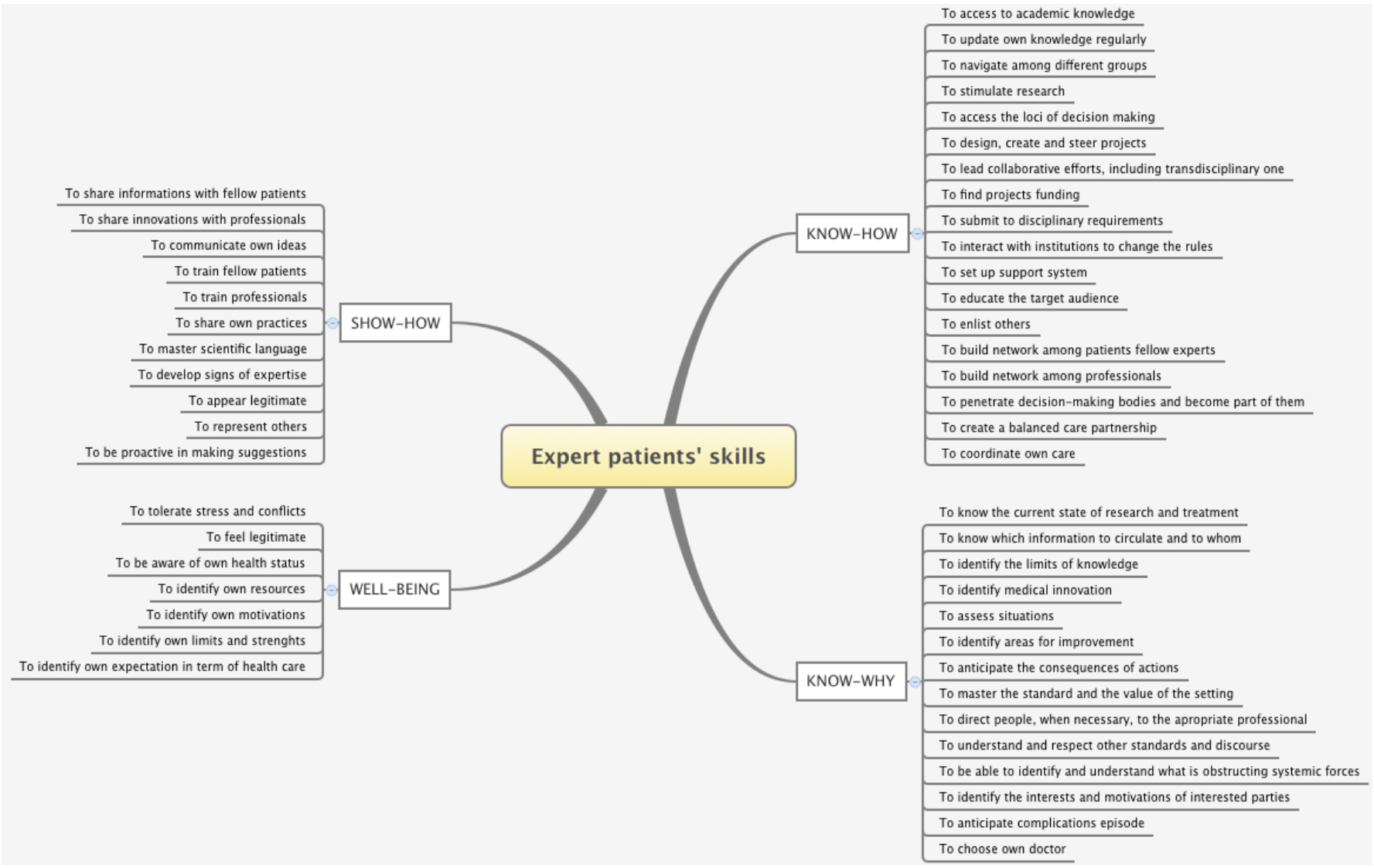

Figure 1. The contributory objectives related to know-how, show-how, know-why and well-being skills. - Relation entre les objectifs contributifs et les savoir-faire, faire-savoir, savoir-être et savoir-analyser.

The expert patients in our study report that their feelings of usefulness and efficacy have helped give the ordeal of their illness meaning. Those words are more evocative of the concept of salutogenesis [18] than of resilience [19], because what predominates in these patients is not the fact of having been able to adapt to their disease, but of being able to manage the events in their lives.

Similarly, while illness is known to contribute to social withdrawal, expert patients exhibit prosocial behaviour, toward both their peers - for whom they feel a participatory-type altruism that leads them to transfer their expertise with empathy and the health professionals with whom they interact on a daily basis.

Moreover, they are passionate about their expert patient activities, and this characteristic is also found in their relationship to knowledge.

\section{Future prospects}

Expert patients can play an important role, provided the risk of idealizing them - a risk inherent in the study methodology - is taken into account. That risk can be reduced by collecting the opinions of professionals who have collaborated with expert patients. Such professionals could provide feedback on negative cases that would help with setting limits, although expert patients do appear to fill useful functions, including in public health. Indeed, the competency that public health epidemiologists are currently exploiting, with expert patient consent, is the latter's ability to interpret and translate data, which benefits decision-making processes [20]. As our results show, when they are spokespeople for the patient community with which they identify (those affected by the same condition, the same problems, or the same care facility), expert patients act as translators. They also translate in the reverse direction; by informing and educating their peers, they increase access to information, which may ultimately help reduce health care disparities.

In the current, relatively non-competitive, context, we could probably estimate that nearly all patients who do things on behalf of the community are expert patients. But in some activities, like therapeutic education, where the number of patients is starting to get large, only those patients capable of training others to do it, and then capable of self-analysis and meta-analysis, and ultimately capable of reforming practices, should probably be considered experts.

While it may be possible to train patients in different practices, like the ones employed by user representatives, 
educators, trainers or lobbyists, given what we know about emotional skills and emotional intelligence and given the nature of self-reliance skills themselves, hoping to produce patient experts de novo seems futile. The personality traits found by this study, however, might help us identify the types of patients capable of becoming competent social actors, and the thirteen competencies could lay the foundation for a reference to be used for patient self-evaluation and/or to enhance the contents of teaching materials.

\section{Conclusion}

This study helped elucidate the function of expert patients, while providing information on the type of patients for whom this designation should be reserved. The results also helped define a position regarding training aimed at producing expert patients.

With regard to the skills deployed by expert patients and their personality traits, we can now define them as people with a chronic illness who are constantly educating themselves about their illness and who help improve its treatment and/or prevention. More precisely, they are passionate social actors who subscribe to an ethic of efficacy, which inspires them to contribute to innovation (in therapeutics, management, regulatory issues, the health care system, etc.) and an ethic of usefulness, which leads them to differentiate themselves from professionals, carry out actions that address institutional oversights, and adopt prosocial behaviours that prompt them to share their expertise and conduct altruistic actions.

\section{References}

1. Laverack G, Labonte R. A planning framework for community empowerment goals within health promotion. Health Policy Plan 2000; 15:255-262.

2. Houssin D. Independence and expertise: public health and prevention of conflicts of interests. Pouvoirs, Revue française d'études constitutionnelles et politiques, Les conflits d'intérêts, 2013; 147:111-121.

3. Schwab M, Syme L. On Paradigms, community participation, and the future of public health, Am J Public Health 1997; 87:2049-2051.

4. Epstein S. Impure science: AIDS, activism and the politics of knowledge. University of California Press; 1996.

5. Akrich M, Raheharisoa V. L'expertise profane dans les associations de patients : un outil de démocratie sanitaire. Santé publique 2012; 24:69-74.
6. Lorig K, Ritter PL, Dost A, Plant K, Laurent DD, McNeil I. The expert patients programme online a 1 year study of an internet based self management programme for people with long term conditions. Chronic Illn 2008; 4:247-256.

7. Flora L. Le patient formateur, un nouveau métier pour accompagner un nouveau paradigme au sein du système de santé. In: Jouet E, Las Vergnas O, Noel-Hureaux E (coord.), Nouvelles interventions réflexives dans la recherche en santé : du savoir expérientiel des malades aux interventions des professionnels de santé. Paris: Archives contemporaines; 2014, pp. 21-41.

8. Cohen JD, Tropé Chirol S. Les patients dans les programmes d'ETP. Revue du rhumatisme 2013; 80:197-201.

9. Grimaldi A, Sandrez C. Les patients experts en diabétologie : ce concept a-t-il vraiment un intérêt ? Diabète et obésité 2013; $8(68): 120-122$.

10. Morse J, Barrett M, Mayan M, Olson K, Spiers J. Verification strategies for establishing reliability and validity in qualitative research. Int J Qualit Meth 2002; 1(2):13-22.

11. Epstein S. Impure science: AIDS, activism and the politics of knowledge. University of California Press; 1996.

12. Leclercq D. Aadopease : un acronyme des compétences des soignants-éducateurs en ETP. Educ Ther Patient/Ther Patient Educ 2014; 6(1):10201.

13. Perrenoud P. L'autonomie : une question de compétence ? Résonances 2002; 1(septembre):16-18.

14. Bennett J.M. Contemporary leadership and intercultural competence: Understanding and utilizing cultural diversity to build successful organizations, ed. M.A. Moodian, 2000, 95-110. Thousand Oaks, CA: Sage.

15. Collet B. Binationale Paare und Familien in Frankreich und Deutschland: Die Auswirkungen des rechtlichen Status auf die Integrationsmodi inländisch verheirateter Ausländer, in: Alber J.-L. et al. (dir.), Mariages Tous Azimuts. Approche pluridisciplinaire des couples binationaux. Grenzüberschreitend Heiraten. Binationale Paare in pluridisziplinärer Perspektive. Fribourg, Suisse : Editions universitaires 2000, p. 103-119.

16. Boyatzis RE, Goleman D, Rhee K. Clustering competence in emotional intelligence: insights from the emotional competence inventory (ECI). In: Bar-On R, Parker JDA (eds.), Handbook of emotional intelligence. San Francisco: Jossey-Bass; 2000, p. 343-362.

17. Bandura A. Self efficacy mechanism in human agency. Am Psychol 1982; 37:122-147.

18. Antonowski A. Unraveling The Mystery of Health - How People Manage Stress and Stay Well. San Francisco: Jossey-Bass, 1987.

19. Rutter M. Resilience concepts and findings: implication for family therapy. J Family Ther 1999; 21:119-144.

20. Bondy S. Identifying core competencies for public health epidemiologists. Revue Canadienne de Santé Publique 2008; 99:246-251. 